\title{
Impact of Alternative Raw Materials on the Profitability of a Large-Scale Bio-Coal Pellet Plant in Finland
}

\author{
Jarno Föhr*, Raghu KC, Kalle Karttunen, Tapio Ranta \\ Laboratory of Bioenergy, Lappeenranta-Lahti University of Technology LUT, Mikkeli, Finland \\ Email: *jarno.fohr@lut.fi
}

How to cite this paper: Föhr, J., KC, R., Karttunen, K. and Ranta, T. (2019) Impact of Alternative Raw Materials on the Profitability of a Large-Scale Bio-Coal Pellet Plant in Finland. Journal of Sustainable Bioenergy Systems, 9, 1-15.

https://doi.org/10.4236/jsbs.2019.91001

Received: March 1, 2019

Accepted: March 26, 2019

Published: March 29, 2019

Copyright $\odot 2019$ by author(s) and Scientific Research Publishing Inc. This work is licensed under the Creative Commons Attribution International License (CC BY 4.0).

http://creativecommons.org/licenses/by/4.0/

\begin{abstract}
The aim of this paper was to compare the annual economic impact of a large-scale bio-coal pellet plant by raw material specifically for the Finnish Lakeland region. In this study, the total production volume of the theoretical plant was 200,000 tons per year and the raw wood materials used were birch pulpwood, spruce pulpwood, pine pulpwood, and energy wood. These wood materials were young delimbed wood from early thinnings. The main goal of the paper was to illustrate that the energy content differences of raw wood materials affect the economic profitability of a bio-coal pellet plant at regional level. In this case, wood type also has a regional economic impact, which the pellet plant can influence through its raw wood material choices. The raw material comparison was based on measured data and not computational or literary data alone. The study found that lower solid wood energy densities caused higher relative costs for the total supply chain. A parallel phenomenon occurred with the required gross margin of the pellets, where lower energy content caused higher required gross margin for pellet sales. The gross margin was also sensitivity analyzed at different discount rates from $5 \%$ to $20 \%$. At each required discount rate, the highest annual economic impact on the region was found for birch pellets, with values of $36.95-42.66$ million $€$. Spruce pellets had the smallest annual economic impact, although it had the highest final pellet price in the same cases. The different economic effects were caused by the energy volumes sold.
\end{abstract}

\section{Keywords}

Bio-Coal, Pellet, Plant, Profitability, Raw Material, Region

\section{Introduction}

The use of fossil fuels is still high in the world, causing global warming as a re- 
sult of greenhouse gas emissions, thereby reducing the global balance of nature, not to mention rising sea levels, melting glaciers, and increasing extreme weather phenomena. A lot of new technologies are being developed to replace or at least reduce the use of fossil fuels. The world's most used non-fossil raw material is produced for fuel production in three different thermo-chemical conversion ways - torrefaction, pyrolysis, and gasification - to achieve solids, liquid, and gas respectively from biomass [1]. Biomass is widely considered as an ideal energy resource for replacement of fossil fuels due to the zero carbon emission and renewable characteristics [2]. Nevertheless, biomass has a low energy density, which causes high transportation and handling costs. The key to resolving this problem is locating the energy conversion process close to a concentrated source of biomass [3].

A bio-coal pellet plant is a modern and effective solution to increase the degree of local processing of biomass by pre-treatment and pelletization. Torrefaction was the principal pre-treatment process in this paper [4]. Torrefaction is a thermochemical treatment of biomass in the low-temperature range of $200^{\circ} \mathrm{C}$ $300^{\circ} \mathrm{C}$ [5] [6]. The aim of the treatment is to refine the biomass to a high-quality solid biofuel of high energy density that can be used for combustion purposes. Biomass loses relatively more oxygen and hydrogen than carbon during the torrefaction process when the calorific value of the raw material increases [7]. The lower heating value (LHV) of torrefied biomass is typically around $18-23 \mathrm{MJ} / \mathrm{kg}$ [8]. The end product is a torrefied wood pellet with a high energy density whose handling and transportation are economical in the next steps of the supply chain [9]. The significant improvement in the energy density of the wood biomass can mean that transportation-related costs can be halved following torrefaction [10].

The physical properties such as higher energy content and grindability make torrefied pellets suitable for co-firing with coal. A study by Ndibe et al. [11] suggests that torrefied pellets can be mixed with coal in pulverized coal furnace with high share up to $100 \%$ full conversion. An increasing number of industrialized nations have committed themselves to increase renewable energy source to lower their $\mathrm{CO}_{2}$ emissions and bioenergy is a potential mid-term solution. Furthermore, since torrefied pellets could potentially replace the coal, the investment for the retrofit would be significantly lower than building a completely new energy system [12]. Thus, ultimately, torrefied pellets could be the potential solution to the energy transition towards low-carbon energy system.

The main aim of this paper was to determine the regional added value of a theoretical large-scale bio-coal pellet plant for the region of South Savo. The regional added value is the direct economic effects on the region from operation of the plant. A further goal was to compare the differences in economic impact arising from differing energy content of the raw wood material used. The total production volume of the plant was assumed to be 200,000 tons per year and the total capital investment of the plant was assumed to be 45.5 million euros based on the study by Svanberg et al. [13]. Karttunen et al. [14] studied the total regional socio-economic benefits of sawmill and bio-coal investments, which were supported by the intensive forest management at the South Savo region. As a 
result, the regional benefits could be annually $2.8 \%(150 \mathrm{M} €)$ for GDP more than in BAU scenario by 2030 including multiplier effects [14].

In the first part of the work, the annual raw material demand of the plant was calculated in solid cubic meters. Material demand was calculated for the four different raw wood materials studied based on their calorific values. In the second phase, the total supply costs were calculated by work stage for each raw material. In the third phase, the net present value (NPV) and internal rate of return (IRR) were used to determine the required gross margin for the pellet types produced. The gross margin was then examined more closely by sensitivity analysis for discount rates of $5 \%, 10 \%, 15 \%$, and $20 \%$. In the last phase, the final price for each pellet type was determined when the total supply costs were added to the required gross margin. The approach used enables comparison of the direct annual economic impact of the plant by raw material for the specific Finnish region studied.

This paper extends earlier work by Föhr et al. [15], which investigated manufacturing of torrefied pellets in a ton-scale pilot plant and determination of the energy content of pellets made from different wood species. This paper contributes to literature in the field because previous studies have not specifically considered the economic significance of bio-coal pellet plants on the region in which they are located. In addition, the effect of differences in raw wood materials on bio-coal pellet plants has remained a somewhat neglected topic, which is somewhat surprising as the energy content of the raw material decisively influences the profitability of pellet plants.

\section{Regional Source Information}

There is a lack of large-scale processing industries in many regions in Finland, particularly in northern and eastern areas, and this is also true for the region of South Savo, located in south-eastern Finland (Figure 1). The surface area of the region is $19,130 \mathrm{~km}^{2}$ and it has a population of more than 147,000 people [16]. South Savo is the most forested area in Finland and the economic importance of forests and forestry is significant. For example, in 2017, forest owners of South Savo had gross stumpage earnings of 261.2 million euros [16]. Currently, the region's pulpwood is not processed in South Savo but sold as raw wood for the pulp mills of neighboring regions.

The total wood supply of the region of South Savo is shown in Figure 2. In the figure, the total forest biomass supply is divided into different wood product groups. The total supply volume in 2017 was 7.44 million cubic meters. The total timber share was 3.66 million cubic meters and total pulpwood share 3.31 million cubic meters, respectively. Energy wood had the lowest share of 0.47 million cubic meters [17].

The most interesting wood product groups from the perspective of this study are the pulpwood groups and energy wood, because they are potential raw materials for bio-coal pellet production as regard price and quality. According to statistics from the state Natural Resources Institute Finland, pine pulpwood in South Savo consists of Scots pine (Pinus sylvestris) and spruce pulpwood is Norway spruce (Picea abies). Hardwood pulpwood comprises only young birchwood 


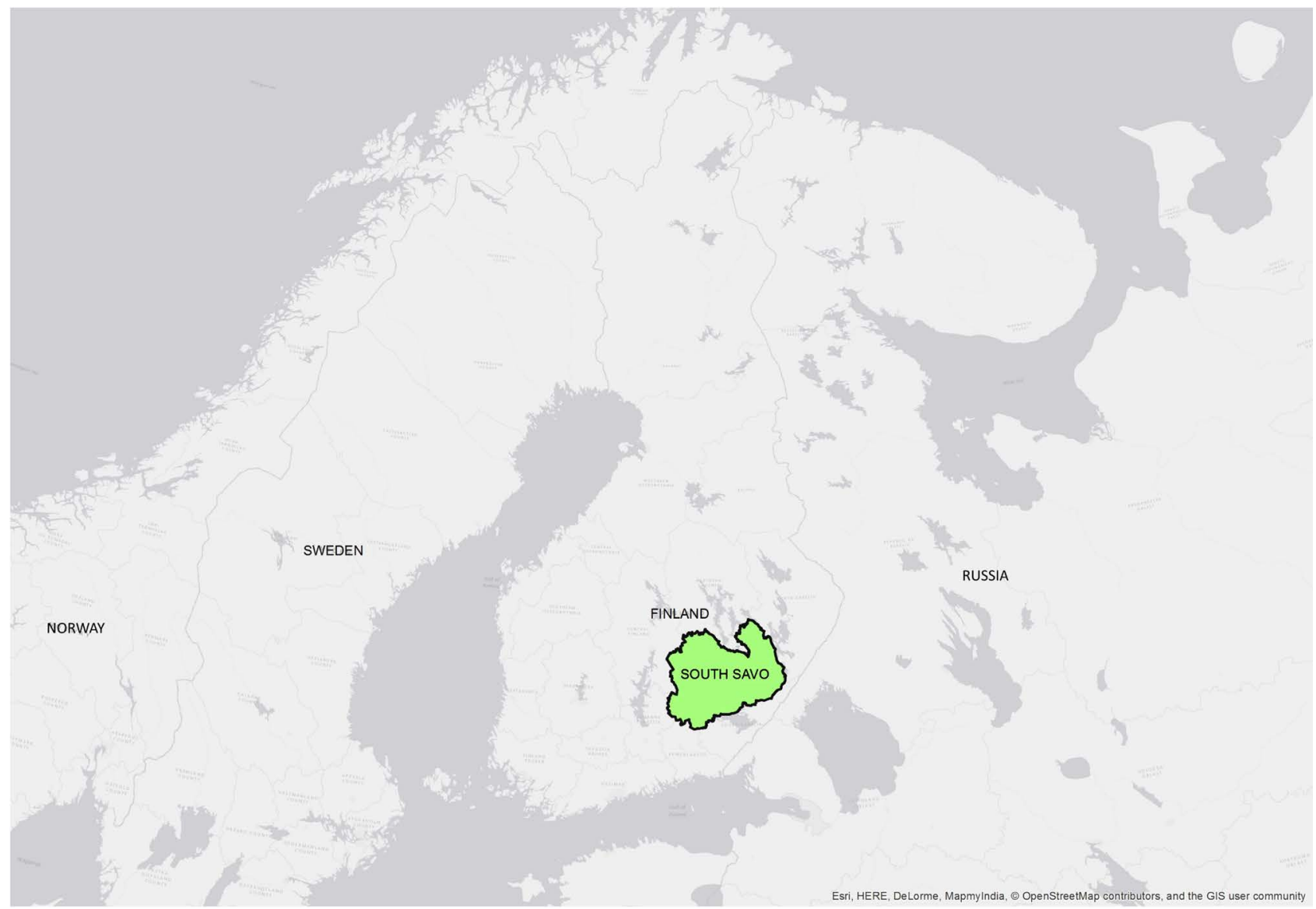

Figure 1. Region of South Savo in Finland.

2017

\begin{tabular}{l|lll|l|l|l}
1.41 & 2.01 & 0.24 & 1.25 & 1.07 & 0.99 & 0.47
\end{tabular}

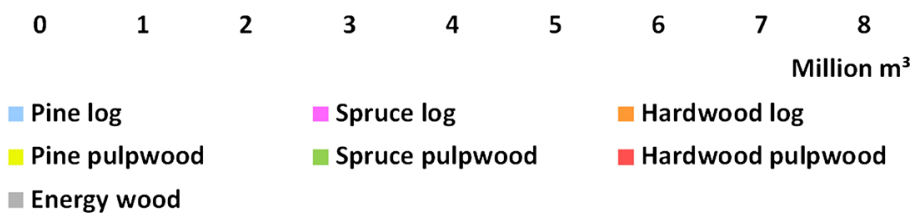

Figure 2. Total wood supply of South Savo in 2017 [17].

species like downy birch (Betula pubescens) and silver birch (Betula pendula). Energy wood contains mixed wood species and, usually, most of it is hardwood. Energy wood consists of different parts of the tree such as young delimbed stems, small whole trees and logging residues that are not suitable for industrial production [18].

\section{Material and Methods}

\subsection{Material}

Young delimbed wood of early thinnings was used as the raw wood material of 
the plant. It is best known as pulpwood, which has a diameter at breast height $(\mathrm{DBH})$ of $5-15 \mathrm{~cm}$ and a length of $2.7-5.0 \mathrm{~m}$ [19]. This kind of wood is not suitable for sawing due to its size and quality. The different raw wood materials used in the plant production modeling in this study were birch, spruce, pine and energy wood. They were chosen because they are the most common wood species in Finland. The energy wood is composed of mixed hardwood. The plant's raw wood material flow did not contain logging residues.

The bio-coal pellet plant's raw material supply chain starts from the forest. First, trees of pulpwood size are felled by a felling machine in thinning operations and the delimbed stems are forwarded to a stack on the roadside (Figure 3). The delimbed stems are then transported to the plant by a full-trailer log truck. Next, the delimbed stems are chipped in a transferable medium sized chipper at the plant. The produced woodchips are then transferred to torrefaction and pellet production. Finally, the finished bio-coal pellet products are distributed worldwide.

\subsection{Methods}

\subsubsection{Energy Volume of Annual Production}

The energy volume of annual production at the plant was determined individually for all three puplwoods and the energy wood. The plant's energy volume of annual production in megawatt-hours was calculated with Equation (1), which is taken from the publication of Alakangas et al. [20]:

$$
W=\frac{Q_{n e t, d} \times\left(\frac{100-M_{a r}}{100}\right)-0.02443 \times M_{a r}}{3.6} \times m
$$

where

$W \quad$ is energy volume of annual production, $\mathrm{MWh}$,

$Q_{n e t, d}$ is net calorific value on a dry basis, is also known as LHV, MJ/kg,

$M_{a r} \quad$ is moisture content as received, $\mathrm{w}-\%$,

0.02443 is a correction factor for the enthalpy of vaporization for water (moisture) at a temperature of $25^{\circ} \mathrm{C}, \mathrm{MJ} / \mathrm{kg}$ per $1 \mathrm{w}-\%$ of moisture,

3.6 converts the unit $\mathrm{MJ} / \mathrm{kg}$ into the $\mathrm{MWh} / \mathrm{t}$,

$\mathrm{m}$ is annual production volume of the plant, in tons.

Equation (1) includes also the energy content calculation, which is shown in Equation (2).

$$
E=\frac{Q_{n e t, d} \times\left(\frac{100-M_{a r}}{100}\right)-0.02443 \times M_{a r}}{3.6}
$$

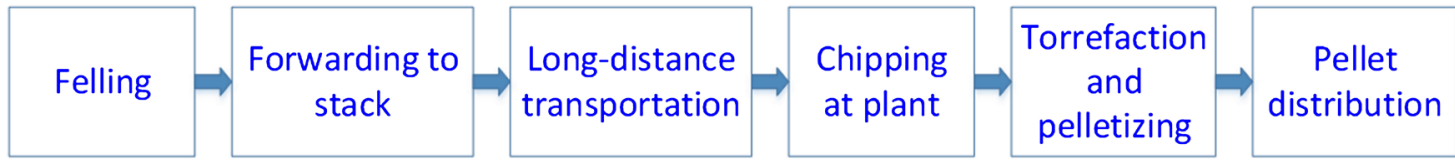

Figure 3. Raw material flow from forest to end users. 
where $\mathrm{E}$ is energy content, $\mathrm{MWh} / \mathrm{t}$.

The moisture content of all pellet products $\left(\mathrm{M}_{\mathrm{ar}}\right)$ was set at $6.0 \%$ in the initial calculations. The selected moisture content is an average value of the torrefied pellets from the study of Föhr et al. [15], which considered the same wood species as this study. LHV values are also taken from the same study [15]. The annual production volume of the bio-coal pellet plant $(\mathrm{m})$ was assumed to be 200,000 tons and the same production volume was used for each wood product group. The study examined four alternative cases for raw material sources of the bio-coal pellet plant.

\subsubsection{Raw Material Demand}

The raw material demand of the bio-coal pellet plant was calculated at a plant energy efficiency of $90 \%$. The energy efficiency of the plant was set based on the assumption of many researchers that mass loss of around 30\% provides the best bio-coal pellet product in terms of calorific value [21] [22]. The energy loss for this mass loss is usually around $10 \%$ [23].

The weight of the woodchips used annually was calculated when the factor $\mathrm{m}$ (annual production volume of the plant in tons) was solved from Equation (1). The factor $\mathrm{W}$ (energy volume of annual production) is already known from previous calculations. In the weight calculations, the LHV of the woodchips $\left(\mathrm{Q}_{\mathrm{net,d}, \mathrm{d}}\right)$ was assumed to be the same as that of the end product itself, because total moisture content does not affect this value. The as-received moisture content of the woodchips $\left(\mathrm{M}_{\mathrm{ar}}=51.5 \%\right)$ was the average value from the study of Föhr et al. [15]. The volume of woodchips was calculated by multiplying the weight of woodchips (m) by the average bulk density of $331 \mathrm{~kg} / \mathrm{m}^{3}$ [15]. Subsequently, the plant's raw material demand in cubic meter volume was obtained by multiplying the volume of woodchips by a factor of 0.4 , which is a conversion value from the bulk volume to the cubic meter volume [20] [24]. Finally, the energy density of the solid wood was obtained by dividing the raw material need of the plant by the volume of solid wood.

\subsubsection{Total Supply Costs}

All supply cost data was allocated to the year 2017 in this study. Since young delimbed pulpwoods and delimbed energy wood were the cheapest source at market prices in the region of South Savo, they were chosen to be the raw wood materials for the bio-coal pellet plant. In 2017, the average stumpage price was $10.95 € / \mathrm{m}^{3}$ for birch pulpwood, $10.60 € / \mathrm{m}^{3}$ for spruce pulpwood, $11.29 € / \mathrm{m}^{3}$ for pine pulpwood, and $5.75 € / \mathrm{m}^{3}$ for delimbed energy wood. The stumpage prices of the woods were taken from the price statistics for South Savo compiled by the Natural Resources Institute Finland [25] [26].

The total costs of felling and forest transportation were taken from data for 2017 presented by Metsäteho Oy, a R\&D organization owned by leading Finnish forest industry actors which has maintained annual statistics in this area [27]. The above-mentioned costs formed the total stack cost at the roadside, which 
was $14.44 € / \mathrm{m}^{3}$ for birch pulpwood, $12.75 € / \mathrm{m}^{3}$ for spruce pulpwood, $12.44 € / \mathrm{m}^{3}$ for pine pulpwood and $16.81 € / \mathrm{m}^{3}$ for delimbed energy wood.

The average unit cost was $7.1 \mathrm{cent} / \mathrm{m}^{3} / \mathrm{km}$ for long-distance transportation $(>100 \mathrm{~km})$, which was also taken from the statistics of Metsäteho Oy [27]. The required raw wood material was assumed to be available in the surrounding area of the plant within a radius of $160 \mathrm{~km}$. The average transport distance for all raw wood materials was set at 80 kilometers [28]. Hence, the average transportation cost was $5.68 € / \mathrm{m}^{3}$ for all raw wood materials.

The average chipping cost was $6.8 € / \mathrm{m}^{3}$ for all raw wood materials, based on the study by Rinne [29]. Rinne assessed the costs of wood fuel chipping and crushing and this average chipping cost was for a medium-sized chipper at intermediate storage, which can be equated to the situation at the bio-coal pellet plant in this study.

The whole production costs of the bio-coal pellet plant were $9.86 € / \mathrm{MWh}$ and the cost of pellet distribution was $3.01 € / \mathrm{MWh}$ [13]. These costs were selected from the base scenario study of Svanberg et al. [13], which also focused on torrefaction technology. The research of supply chain cost evaluation of a bio-coal pellet plant study can be considered in line with this study because the same scale was investigated at the plant level. In addition, the research used data for Sweden, whose costs and cost structure can be considered to correspond to those of the Finnish region studied in this work.

\subsubsection{Required Gross Margin of Pellet}

In this study, NPV and IRR were used to determine the required gross margins of each produced pellet type (Equation (3)). IRR is a rate of interest that calculates NPV of all cash flows from the project of the bio-coal pellet plant as equal to zero. The IRR calculations rely on the same equations as NPV.

$$
\mathrm{NPV}=\sum_{t=1}^{T} \frac{C_{t}}{(1+r)^{t}}-C_{0}
$$

where

NPV is net present value, is equal to zero,

$C_{t} \quad$ is annual cash flow, $€$,

$r$ is discount rate,

$t \quad$ is number of years,

$C_{0} \quad$ is total investment cost, $€$.

The annual cash flow $\left(C_{t}\right)$ consists of two different factors: cash flow from the energy volume of annual production $(W)$ and the required gross margin of the bio-coal pellet. Thus, Equation (4) can be written:

$$
\mathrm{NPV}=\sum_{t=1}^{T} \frac{W \times R}{(1+r)^{t}}-C_{0}
$$

where $R$ is required gross margin, $€ / \mathrm{MWh}$

The required gross margin of the bio-coal pellet $(R)$ was solved from Equation 4 for when the NPV was equal to zero. The gross margin $(R)$ was sensitivity 
analyzed by different discount rates of $5 \%, 10 \%, 15 \%$, and $20 \%$. The plant's repayment period $(t)$ was set at 20 years. The total investment cost of the plant

$\left(C_{0}\right)$ was 45.5 million euros. Using the model developed by the study of Svanberg et al. [13], the total personnel requirement for the size of plant studied was 23 staff working on a full-time basis.

\subsubsection{Final Price of Pellet and Annual Economic Impact}

The final price of each produced pellet type was obtained by adding the total supply costs and the required gross margin $(R)$. Finally, the annual economic impact of the bio-coal pellet plant was obtained by multiplying the final price of the pellet by the energy volume of annual production $(W)$. These calculations were made by raw material specifically.

\section{Results}

\subsection{Energy Volume of Annual Production}

Production information of the bio-coal pellets is presented in Table 1. The LHV of the bio-coal pellets (torrefied) was taken from the study of Föhr et al. [15]. The energy contents of the pellets were calculated using Equation (2). Equation (1) was used in calculation of the energy volume of annual production. The raw material need of the plant was calculated with a production efficiency of $90 \%$. Thus, the calculated average raw material need of the plant was $1118 \mathrm{GWh}$ annually.

\subsection{Raw Material Demand}

The raw material demand of the plant was calculated from the forest side for fresh wood. The calculation results of the weight and volume of woodchips, and the volume and energy density of solid wood are shown in Table 2. Based on these values, the required average cubic meter volume to meet the plant's annual need was 596,000 $\mathrm{m}^{3}$. The energy density of solid wood varied between 1.77 $\mathrm{MWh} / \mathrm{m}^{3}$ and $1.94 \mathrm{MWh} / \mathrm{m}^{3}$ by raw material.

\subsection{Total Supply Costs}

Total supply costs for the different raw wood materials are shown in Figure 4.

Table 1. Production information of the bio-coal pellets.

\begin{tabular}{ccccc}
\hline Bio-coal pellet $^{\mathrm{a}}$ & $\begin{array}{c}\mathrm{LHV}^{\mathrm{b}} \\
(\mathrm{MJ} / \mathrm{kg})\end{array}$ & $\begin{array}{c}\text { Energy content } \\
(\mathrm{MWh} / \mathrm{t})\end{array}$ & $\begin{array}{c}\text { Energy volume of annual } \\
\text { production (GWh) }\end{array}$ & $\begin{array}{c}\text { Raw material need } \\
(\mathrm{GWh})\end{array}$ \\
\hline Birch & 19.37 & 5.02 & 1003 & 1115 \\
Spruce & 18.47 & 4.78 & 956 & 1063 \\
Pine & 19.96 & 5.17 & 1034 & 1149 \\
Energy wood & 19.91 & 5.16 & 1032 & 1146 \\
Average & $\mathbf{1 9 . 4 3}$ & $\mathbf{5 . 0 3}$ & 1006 & 1118 \\
\hline
\end{tabular}

${ }^{\mathrm{a}}$ Moisture content of pellet (6.0\%); ${ }^{\mathrm{b}}$ Lower heating value (low). 
Table 2. Required weights and volumes by raw material. The table also presents the energy densities of solid wood for the materials studied.

\begin{tabular}{|c|c|c|c|c|}
\hline $\begin{array}{c}\text { Raw material } \\
\text { of pellet }^{\mathrm{a}}\end{array}$ & $\begin{array}{c}\text { Weight of } \\
\text { woodchips }(t)\end{array}$ & $\begin{array}{l}\text { Volume of woodchips } \\
\left.\text { (bulk-m } \mathrm{m}^{3}\right)\end{array}$ & $\begin{array}{l}\text { Volume of solid } \\
\text { wood }\left(\mathrm{m}^{3}\right)\end{array}$ & $\begin{array}{l}\text { Energy density of solid } \\
\text { wood }\left(\mathrm{MWh} / \mathrm{m}^{3}\right)\end{array}$ \\
\hline Birch & 493,000 & $1,490,000$ & 596,000 & 1.87 \\
\hline Spruce & 497,000 & $1,501,000$ & 600,000 & 1.77 \\
\hline Pine & 491,000 & $1,484,000$ & 594,000 & 1.94 \\
\hline Energy wood & 491,000 & $1,484,000$ & 594,000 & 1.93 \\
\hline Average & 493,000 & $1,490,000$ & 596,000 & 1.88 \\
\hline
\end{tabular}

${ }^{\mathrm{a}}$ Moisture content as received (51.5\%).

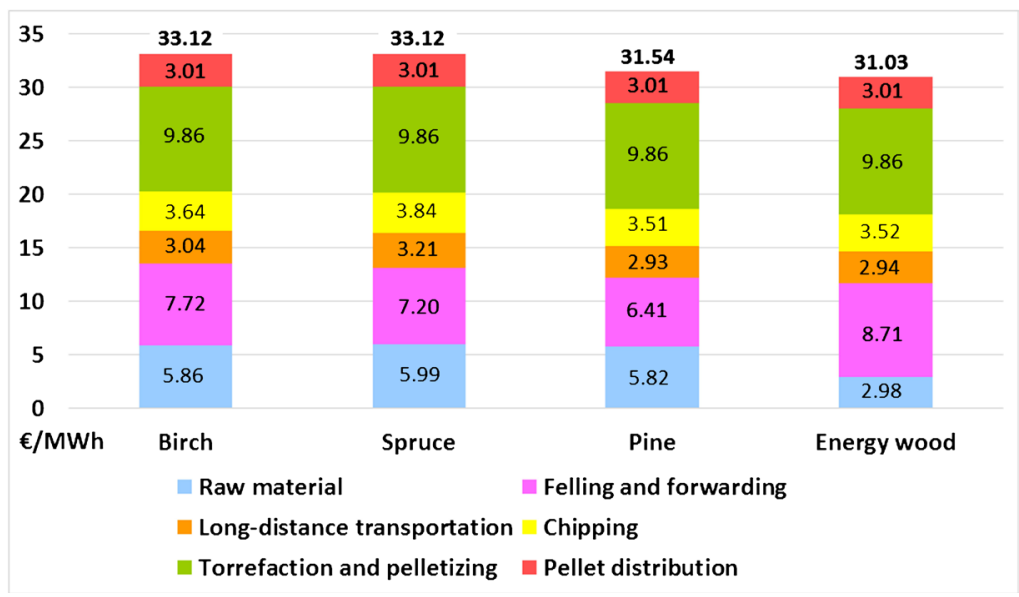

Figure 4. Total supply costs for different raw wood materials.

The costs were distributed by cost category. The unit cost $€ / \mathrm{m}^{3}$ was converted to unit cost $€ / M W h$ by dividing unit cost $€ / \mathrm{m}^{3}$ with the energy density of the solid wood. The total supply cost was $33.12 € / \mathrm{MWh}$ for the birch and spruce pulpwood, $31.54 € / \mathrm{MWh}$ for the pine pulpwood, and $31.03 € / \mathrm{MWh}$ for the energy wood.

\subsection{Required Gross Margin of Pellet}

The required gross margins of each produced pellet type are shown in Figure 5. The gross margin was sensitivity analyzed at discount rates of $5 \%$ (a), 10\% (b), $15 \%$ (c) and $20 \%$ (d). The principle was that the plant investment is profitable when NPV $\geq 0 €$ and IRR $\geq$ discount rate. Figure 5 shows in the case of a discount rate of $5 \%$ that these financial circumstances were fulfilled when the gross margin was 3.6 $€ / \mathrm{MWh}$ for pine and the energy wood pellets, $3.7 € / \mathrm{MWh}$ for birch pellets, and $3.9 € / \mathrm{MWh}$ for spruce pellets. In the case of a discount rate of $20 \%$, the corresponding values were $9.1 € / \mathrm{MWh}$ for pine and energy wood pellets, $9.4 € / \mathrm{MWh}$ for birch pellets and $9.8 € / \mathrm{MWh}$ for spruce pellets.

\subsection{Final Pellet Price and Annual Economic Impact}

The final prices of each produced pellet type and the annual economic impact of the plant for the Finnish region studied are shown in Figure 6. The results of 


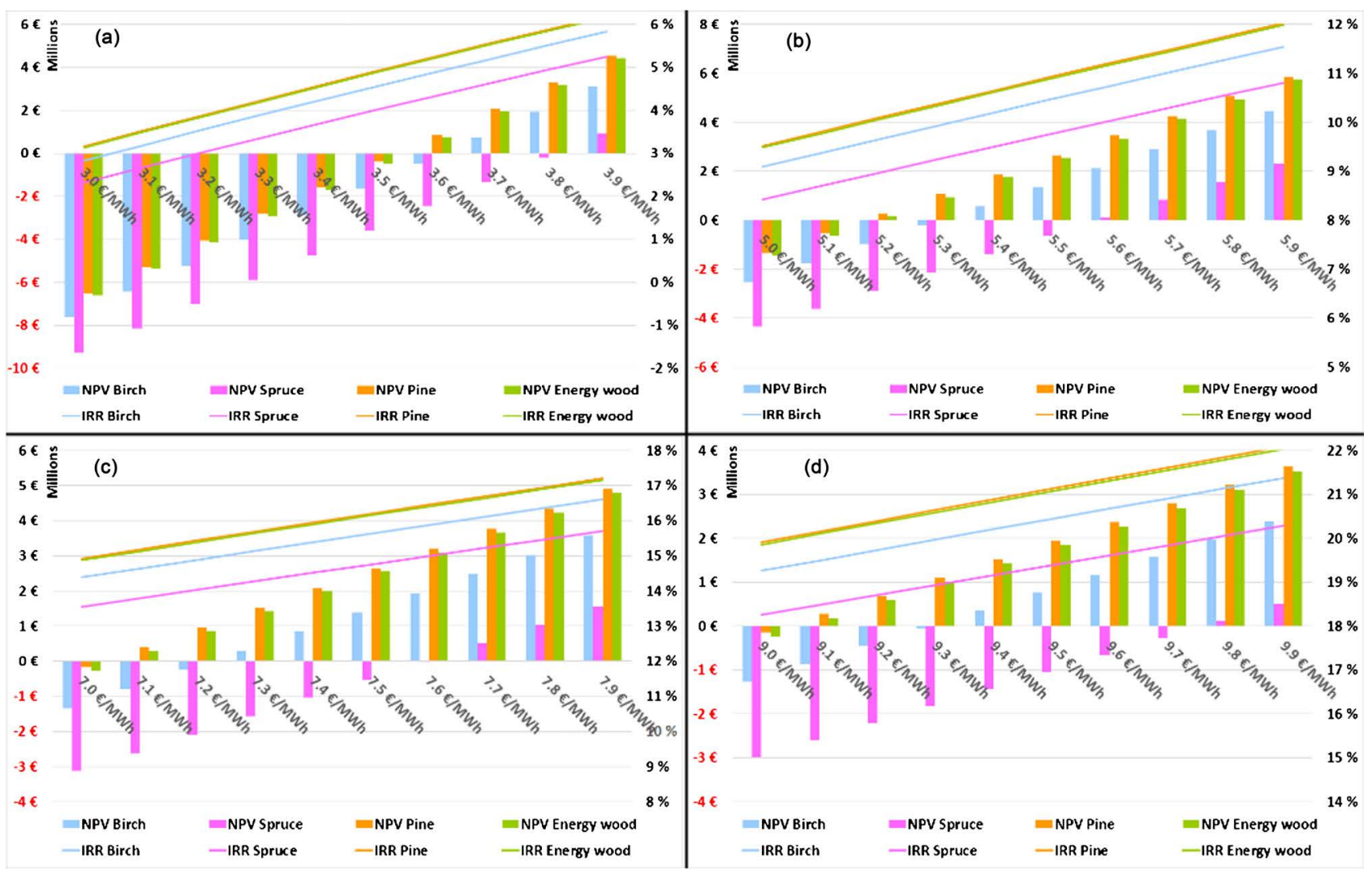

Figure 5. Results of NPV and IRR for each produced pellet type at discount rates of 5\% (a), 10\% (b), 15\% (c) and 20\% (d).

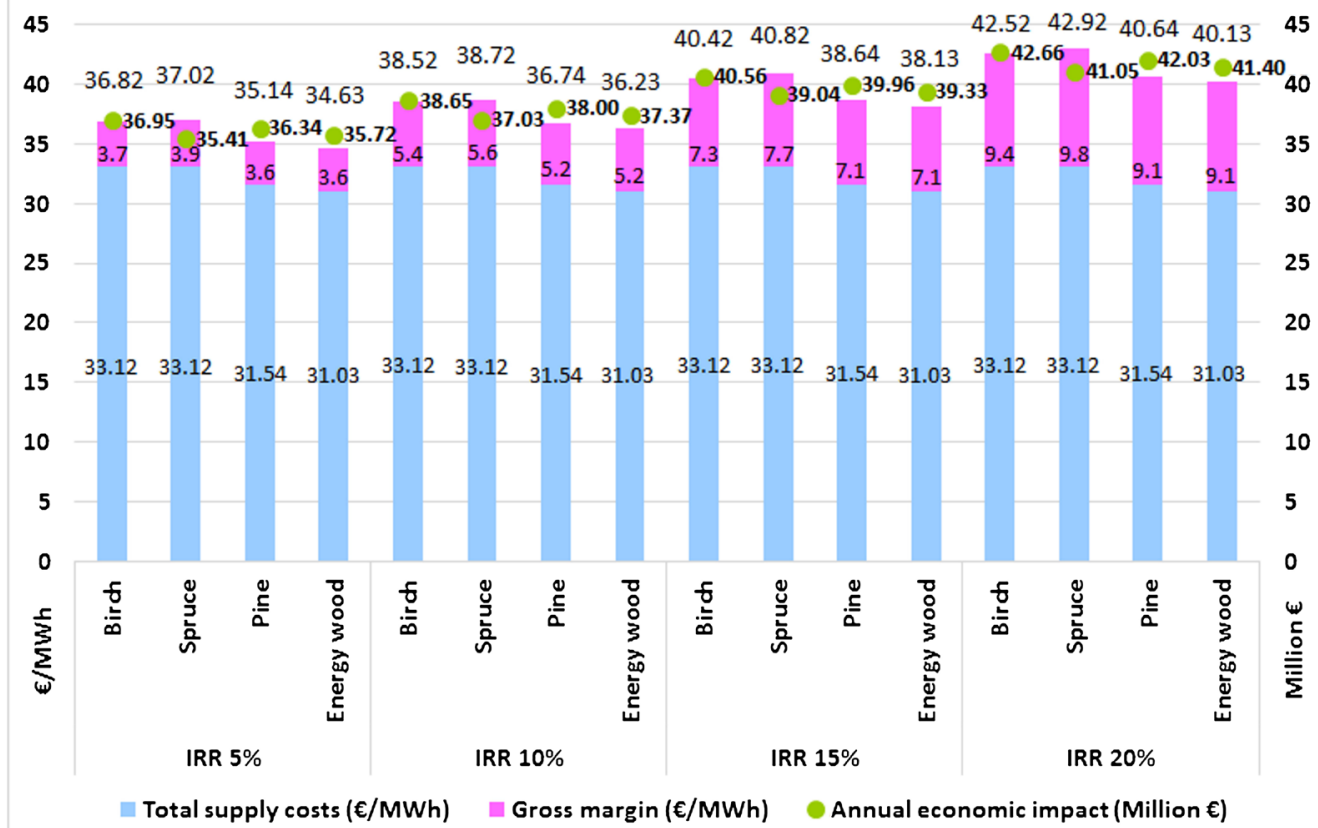

Figure 6. Final prices of the pellets and the annual economic impact for the studied Finnish region. Gross margin of the pellets varied depending on the desired discount rate.

Figure 6 are raw wood-specific and the gross margin of the pellets varied due to the desired discount rate from $5 \%$ to $20 \%$. Figure 6 shows that, at each discount 
rate, the highest final price was obtained for spruce pellets and the lowest for energy wood pellets. However, at each discount rate, the annual economic impact was highest for the birch pellets and lowest for the spruce pellets.

\section{Discussion}

The main aim of the paper was to determine the direct annual economic impact of a large-scale bio-coal pellet plant on the Finnish region of South Savo and to analyze variation in economic impact resulting from differences in the energy content of the raw wood materials used. The theoretical total production volume of the plant was 200,000 tons per year and production efficiency of the plant was $90 \%$. For this case scenario, the required average raw material need was about $596,000 \mathrm{~m}^{3}$ based on the calculations of this study. This volume of raw material demand would increase annual felling capacity by $8 \%$ in the region of South Savo. It is also possible that the effect of the increased demand would be to increase the price of raw wood supply, which would cut into the rate of return, assuming no increase in pellet price. If the pellet price increased, then the plant would become less competitive relative to other pellet suppliers and other energy forms. It was also assumed that the raw wood material arrives at the plant at a moisture content of $51.5 \%$ and the plant produces bio-coal pellets of a moisture content of $6.0 \%$.

In this study, the results for the bio-coal pellets showed that the energy content was $4.78 \mathrm{MWh} / \mathrm{t}$ for spruce, $5.02 \mathrm{MWh} / \mathrm{t}$ for birch, $5.16 \mathrm{MWh} / \mathrm{t}$ for energy wood, and $5.17 \mathrm{MWh} / \mathrm{t}$ for pine. The same internal order of raw materials remained in the results of the fresh solid woods. Correspondingly, the energy density was $1.77 \mathrm{MWh} / \mathrm{m}^{3}$ for spruce, $1.87 \mathrm{MWh} / \mathrm{m}^{3}$ for birch, $1.93 \mathrm{MWh} / \mathrm{m}^{3}$ for energy wood, and $1.94 \mathrm{MWh} / \mathrm{m}^{3}$ for pine. Both the energy content of the pellets and the energy density of the solid woods were lowest for spruce and highest for pine. These numerical values are greatly influenced by the LHVs measured in the previous study of Föhr et al. [15], so the starting values had a research base.

The study noted that lower energy densities of solid wood caused higher relative costs for the total supply chain. A particularly strong effect was seen in the costs of the work stages from the forest to the bio-coal pellet plant. Spruce wood had the highest relative unit costs, and the costs were greatly affected by energy density. The calculations showed that the same volume of wood passed through the supply chain for all the wood species, but differences in the energy density of the wood species caused changes in the relative unit costs. The same phenomenon was also noticed for the gross margin of the pellets. At each studied discount rate from $5 \%$ to $20 \%$, the required gross margin was lowest for pine and energy wood pellets and highest for spruce pellets. The higher energy content allowed a lower required gross margin. The gross margin of the pellets was examined at varying discount rates in order to obtain a more nuanced picture of the effects and better reliability.

Depending on the raw material, the total supply costs of the bio-coal pellets 
were 31.03 - $33.12 € / \mathrm{MWh}$. This study did not examine pellet production costs and distribution costs in detail since Svandberg et al. [13] had previously determined reliable values for Nordic conditions. In the work by Svandberg et al., total supply cost of $31.8 € / \mathrm{MWh}$ was determined in a base scenario, but differences between different raw materials were not examined. In another study, the European Framework Programme 7 Sector Project, the total supply cost was evaluated for a stand-alone plant at $43 € / \mathrm{MWh}$ [30]. In the same work, the corresponding cost for an existing sawmill was $34 € / \mathrm{MWh}$, for a new sawmill 38 $€ / \mathrm{MWh}$, and for a modern pulp mill $33 € / \mathrm{MWh}[30]$. On the other hand, the total supply cost was $39.5 € / \mathrm{MWh}$ according to the study of Ranta et al. [31], who inspected a Finnish bio-coal pellet plant with an annual production volume of 50,000 tons. It should be noted that in these studies the size of the bio-coal pellet plant has a strong impact on the total supply costs.

The calculations in this paper show that the final price of bringing the bio-coal pellets to the market is greatly affected by the raw wood material used. In this study, the lowest pellet price was obtained for energy wood and the highest for spruce at all studied discount rates. An interesting finding was that spruce pellets had the lowest direct annual economic impact on the region when taking into account the energy volumes of annual pellet sales. Sold energy volumes were seen to have a great influence on the annual economic impact on the region. For example, at a discount rate of $10 \%$, the largest annual economic impact was found for birch pellets at 38.65 million $€$, followed by pine pellets at 38.00 million $€$, energy wood pellets at 37.37 million $€$, and spruce pellets at 37.03 million $€$.

\section{Conclusion}

This study investigated the direct annual economic impact of a large-scale bio-coal pellet plant by raw material for a specific Finnish region. It was found that the raw wood material had a major impact on the total supply costs of bio-coal pellets and the resulting profit. Both the energy content of the pellets and the energy density of the solid wood affected the overall profitability of the bio-coal pellet plant and its annual economic impact on the region. It is often assumed in published literature that one solid cubic meter of fresh wood contains two-megawatt hours of energy. This is only an assumption and different raw wood materials have energy content differences, which are mainly affected by the calorific value and moisture content of the wood. In this study, certain moisture content values were fixed in order to make the calculation results comparable. The study demonstrated that the differences in the raw wood material greatly affected the profitability of the bio-coal pellet plant and thus the economic benefit for the whole region.

\section{Acknowledgements}

The authors want to thank the Auramo Foundation for funding that made this study possible. Peter Jones is acknowledged for his help with the English language. 


\section{Conflicts of Interest}

The authors declare no conflicts of interest regarding the publication of this paper.

\section{References}

[1] Basu, P. (2018) Biomass Gasification, Pyrolysis and Torrefaction: Practical Design and Theory. 3rd Edition, Academic Press, Elsevier.

[2] Krzywanski, J., Fan, H., Feng, Y., et al. (2018) Genetic Algorithms and Neural Networks in Optimization of Sorbent Enhanced $\mathrm{H}_{2}$ Production in FB and CFB Gasifiers. Energy Conversion and Management, 171, 1651-1661. https://doi.org/10.1016/j.enconman.2018.06.098

[3] Demirbaş, A. (2001) Biomass Resource Facilities and Biomass Conversion Processing for Fuels and Chemicals. Energy Conversion and Management, 42, 1357-1378. https://doi.org/10.1016/S0196-8904(00)00137-0

[4] van der Stelt, M.J.C., Gerhauser, H., Kiel, J.H.A., et al. (2011) Biomass Upgrading by Torrefaction for the Production of Biofuels: A Review. Biomass and Bioenergy, 35, 3748-3762. https://doi.org/10.1016/j.biombioe.2011.06.023

[5] Prins, M.J., Ptasinski, K.J. and Janssen, F.J.J.G. (2006) Torrefaction of Wood: Part 1. Weight Loss Kinetics. Journal of Analytical and Applied Pyrolysis, 77, 28-34. https://doi.org/10.1016/j.jaap.2006.01.002

[6] Prins, M.J., Ptasinski, K.J. and Janssen, F.J.J.G. (2006) Torrefaction of Wood: Part 2. Analysis of Products. Journal of Analytical and Applied Pyrolysis, 77, 35-40. https://doi.org/10.1016/j.jaap.2006.01.001

[7] Uslu, A., Faaij, A. and Bergman, P.C.A. (2008) Pre-Treatment Technologies, and Their Effect on International Bioenergy Supply Chain Logistics: Techno-Economic Evaluation of Torrefaction, Fast Pyrolysis, and Pelletisation. Energy, 33, 1206-1223. https://doi.org/10.1016/j.energy.2008.03.007

[8] Bergman, P.C.A., Boersma, A.R., Kiel, J.H.A., et al. (2005) Torrefaction for Entrained-Flow Gasification of Biomass. Report: ECN-C-05-067, ECN, Petten.

[9] Pöyry Management Consulting Ltd. (2011) Ristiinaan perustettavan biologistiikkakeskuksen liiketoimintasuunnitelma-Liiketoimintasuunnitelman taustamateriaali [Business Plan of Set up Biologistics Center to Ristiina-Background Material of Business Plan]. Published 31 January 2011.

[10] KC, R., Babu, I., Alatalo, S., et al. (2017) Hydrothermal Carbonization of Deciduous Biomass (Alnus incana) and Pelletization Prospects. Journal of Sustainable Bioenergy Systems, 7, 138-148. https://doi.org/10.4236/jsbs.2017.73010

[11] Ndibe, C., Grathwohl, S., Paneru, M., et al. (2015) Emissions Reduction and Deposits Characteristics during Cofiring of High Shares of Torrefied Biomass in a 500 kW Pulverized Coal Furnace. Fuel, 156, 177-189.

https://doi.org/10.1016/j.fuel.2015.04.017

[12] Kaygusuz, K. and Keleş, S. (2008) Use of Biomass as a Transitional Strategy to a Sustainable and Clean Energy System. Energy Sources, Part A: Recovery, Utilization, and Environmental Effects, 31, 86-97. https://doi.org/10.1080/15567030701468225

[13] Svanberg, M., Olofsson, I., Flodén, J. and Nordin, A. (2013) Analysing Biomass Torrefaction Supply Chain Costs. Bioresource Technology, 142, 287-296. https://doi.org/10.1016/j.biortech.2013.05.048

[14] Karttunen, K., Ahtikoski, A., Kujala, S., et al. (2018) Regional Socio-Economic Im- 
pacts of Intensive Forest Management, a CGE Approach. Biomass and Bioenergy, 118, 8-15. https://doi.org/10.1016/j.biombioe.2018.07.024

[15] Föhr, J., Ranta, T., Suikki, J., et al. (2017) Manufacturing of Torrefied Pellets without a Binder from Different Raw Wood Materials in the Pilot Plant. Wood Research, 62, 481-494. http://www.woodresearch.sk/wr/201703/13.pdf

[16] Tilastot (2018) Englanninkielinen esitysmateriaali (PowerPoint-muodossa) [English Presentation Material (in PowerPoint Format)]. Tilastot [Statistics]. https://www.esavo.fi/tilastot

[17] Natural Resources Institute Finland (2018) Industrial Roundwood Removals by Region 2017. Database Tables. http://stat.luke.fi/en/industrial-roundwood-removals-region-2017_en

[18] Malinen, J., Pesonen, M., Määttä, T., et al. (2001) Potential Harvest for Wood Fuels (Energy Wood) from Logging Residues and First Thinnings in Southern Finland. Biomass and Bioenergy, 20, 189-196. https://doi.org/10.1016/S0961-9534(00)00075-1

[19] Petty, A. and Kärhä, K. (2014) Productivity and Cost Evaluations of Energy-Wood and Pulpwood Harvesting Systems in First Thinnings. International Journal of Forest Engineering, 25, 35-50. https://doi.org/10.1080/14942119.2014.893129

[20] Alakangas, E., Hurskainen, M., Laatikainen-Luntama, J., et al. (2016) Properties of Indigenous Fuels in Finland. VTT Technical Research Centre of Finland, Espoo.

[21] Chin, K.L., H’ng, P.S., Go, W.Z., et al. (2013) Optimization of Torrefaction Conditions for High Energy Density Solid Biofuel from Oil Palm Biomass and Fast Growing Species Available in Malaysia. Industrial Crops and Products, 49, 768-774. https://doi.org/10.1016/j.indcrop.2013.06.007

[22] Lee, J.W., Kim, Y.H., Lee, S.M. and Lee, H.W. (2012) Optimizing the Torrefaction of Mixed Softwood by Response Surface Methodology for Biomass Upgrading to High Energy Density. Bioresource Technology, 116, 471-476. https://doi.org/10.1016/j.biortech.2012.03.122

[23] Asadullah, M., Adi, A.M., Suhada, N., et al. (2014) Optimization of Palm Kernel Shell Torrefaction to Produce Energy Densified Bio-Coal. Energy Conversion and Management, 88, 1086-1093. https://doi.org/10.1016/j.enconman.2014.04.071

[24] Petty, A. and Kärhä, K. (2011) Effects of Subsidies on the Profitability of Energy Wood Production of Wood Chips from Early Thinnings in Finland. Forest Policy and Economics, 13, 575-581. https://doi.org/10.1016/j.forpol.2011.07.003

[25] Natural Resources Institute Finland (2018) Volumes and Prices in Industrial Round Wood Trade. Database Tables. http://stat.luke.fi/en/volumes-and-prices-roundwood-trade

[26] Natural Resources Institute Finland (2018) Volumes and Prices in Energy Wood Trade. Database Tables. http://stat.luke.fi/en/volumes-and-prices-energy-wood-trade

[27] Strandström, M. (2018) Puunkorjuu ja kaukokuljetus vuonna 2017 [Wood Harvesting and Long-Distance Transportation in 2017]. Result Film Series 8a/2018 of Metsäteho Oy.

http://www.metsateho.fi/wp-content/uploads/Tuloskalvosarja_2018_08a_Puunkorj uu_ja_kaukokuljetus_vuonna_2017.pdf

[28] Föhr, J., Karttunen, K., et al. (2017) Regional Added Value of Refining Forest Biomass for Energy Purposes in Finland. Proceedings of 25th European Biomass Conference and Exhibition, Stockholm, 12-15 June 2017, 1598-1601.

[29] Rinne, S. (2010) Energiapuun haketuksen ja murskauksen kustannukset [The Costs 
of Wood Fuel Chipping and Crushing]. Master's Thesis, Lappeenranta University of Technology, Lappeenranta. https://lutpub.lut.fi/handle/10024/74691

[30] Arpiainen, V. and Wilen, C. (2014) Report on Optimisation Opportunities by Integrating Torrefaction into Existing Industries. Deliverable No. D3.2.

[31] Ranta, T., Föhr, J. and Soininen, H. (2016) Evaluation of a Pilot-Scale Wood Torrefcaction Plant based on Pellet Properties and Finnish Market Economics. International Journal of Energy and Environment, 7, 159-168.

https://www.ijee.ieefoundation.org/vol7/issue2/IJEE_05_v7n2.pdf

\section{Nomenclature}

$C_{t} \quad$ is annual cash flow, $€$

$C_{0} \quad$ is total investment cost, $€$

$E \quad$ is energy content, $\mathrm{MWh} / \mathrm{t}$

$M_{a r} \quad$ is moisture content as received, w-\%

$m$ is annual production volume of the plant, in tons

$\mathrm{NPV}$ is net present value, is equal to zero

$Q_{n e t, d} \quad$ is net calorific value on a dry basis, is also known as $\mathrm{LHV}, \mathrm{MJ} / \mathrm{kg}$

$R \quad$ is required gross margin, $€ / \mathrm{MWh}$

$r \quad$ is discount rate

$t \quad$ is number of years

$W \quad$ is energy volume of annual production, $\mathrm{MWh}$

0.02443 is a correction factor for the enthalpy of vaporization for water (moisture) at a temperature of $25^{\circ} \mathrm{C}, \mathrm{MJ} / \mathrm{kg}$ per $1 \mathrm{w}-\%$ of moisture

3.6 converts the unit $\mathrm{MJ} / \mathrm{kg}$ into the $\mathrm{MWh} / \mathrm{t}$ 